Jurnal Akuntansi dan Keuangan

Vol. 10 No. 2 Oktober 2021
FEB Universitas Budi Luhur

p-ISSN: 2252-7141

e-ISSN: 2622-5875

\title{
PERKEMBANGAN PENELITIAN AKUNTANSI PEMERINTAH PADA DUA JURNAL NASIONAL TERAKREDITASI
}

\author{
Zayyan Velda Send ${ }^{1}$ \\ Puji Wibowo ${ }^{2}$ \\ Politeknik Keuangan Negara STAN 1,2 \\ Email: zayyanveldasend@gmail.com ${ }^{1}$,puji.wibowo@pknstan.ac.id ${ }^{2}$
}

\begin{abstract}
The adoption of the accrual basis is a milestone in the reform of government financial reporting. State financial management policies in the new government era also provided new insights for the development of government accounting research. This study aims to provide an overview of the development of government accounting research in two reputable national journals indexed by SINTA 2 during the 2015-2019 period. Article observations are carried out using the chartered fields method. The results of a study of 43 articles show that accountability and spending are the most popular topics to be discussed. Mixed research methods are still very limited to use in these government accounting studies. This study contributes to the direction of government accounting research in the future by providing signals of several interesting research areas to be explored further.
\end{abstract}

Keywords: Accrual, government accounting, state finance

\begin{abstract}
ABSTRAKSI
Penerapan basis akrual merupakan tonggak bersejarah dalam reformasi pelaporan keuangan pemerintah. Kebijakan pengelolaan keuangan negara pada era pemerintahan baru turut memberikan warna bagi perkembangan riset akuntansi pemerintahan. Penelitian ini bertujuan untuk memberikan ulasan mengenai perkembangan riset akuntansi pemerintah pada dua jurnal nasional terakreditasi yang terindeks SINTA 2 selama periode 2015-2019. Pengamatan artikel dilakukan dengan menggunakan metode chartered the fields. Hasil studi terhadap 43 artikel menunjukkan bahwa akuntabilitas dan belanja merupakan topik yang paling populer dibicarakan. Metode riset campuran masih sangat jarang digunakan dalam studi akuntansi pemerintahan tersebut. Studi ini memberikan kontribusi berupa arah riset akuntansi pemerintahan di masa mendatang dengan memberikan sinyal beberapa area penelitian yang cukup menarik untuk didalami lebih lanjut.
\end{abstract}

Kata Kunci: Akrual, akuntansi pemerintah, keuangan negara 


\section{PENDAHULUAN}

Reformasi pengelolaan keuangan negara dimulai sejak tahun 2003 yang ditandai dengan adanya perubahan paradigma secara radikal antara lain terkait akuntansi pemerintahan. Perubahan fenomenal tersebut ditandai dengan terbitnya tiga paket undangundang yaitu, Undang-Undang No. 17 Tahun 2003 tentang Keuangan Negara, UndangUndang No. 1 tentang Perbendaharaan Negara, dan Undang-Undang No. 15 Tahun 2004 tentang Pemeriksaan Pengelolaan dan Tanggung Jawab Keuangan Negara. Lahirnya tiga paket undang-undang tersebut diikuti dengan penerapan standar akuntansi pemerintahan dalam pelaporan keuangan.

Standar Akuntansi Pemerintahan (SAP) yang digunakan semula berbasis Cash Towards Accrual(CTA) yang ditetapkan melalui PP Nomor 24 tahun 2005. Pedoman akuntansi untuk instansi pemerintah pusat dan daerah tersebut pada akhirnya berpindah ke basis akrual dengan terbitnya PP Nomor 71 tahun 2010. Implementasi basis akrual tersebut sebenarnya sedikit terlambat. Hal ini karena sesuai ketentuan UU Nomor 17 Tahun 2003, pemerintah seyogianya menerapkan basis akrual selambat-lambatnya lima tahun sejak terbitnya UU keuangan negara tersebut atau tahun 2008. Keterlambatan tersebut antara lain dipicu oleh faktor kesiapan sumber daya manusia dan dukungan teknologi informasi. Bagaimanapun basis akrual sudah menjadi common practice di negara-negara lain, khususnya OECD. Adopsi basis akrual dalam rangka menjawab kebutuhan informasi yang lebih memadai. Tuntutan mengenai akuntabilitas keuangan, efisiensi, dan dan efektivitas dalam sektor publik membuat organisasi sektor publik di dunia mengalami perubahan (Rizky dan Setiawan, 2019).

Kompetensi akuntansi yang sangat beragam baik di tingkat pusat maupun daerah menjadi pertimbangan bagi Pemerintah untuk memberikan relaksasi bagi implementasi basis akrual. PP 71 tahun 2010 mengatur dua paket SAP sekaligus yaitu SAP basis akrual dan SAP basis CTA. Implementasi basis akrual masih bersifat voluntary sejak tahun 2010. Instansi pusat dan daerah dapat menerapkan basis akrual atau pun tetap berpedoman pada basis CTA sampai dengan akhir tahun 2014. Penerapan basis akrual bersifat mandatory untuk seluruh instansi pemerintahan dalam pelaporan keuangan tahun 2015. Transformasi pelaporan keuangan pemerintah menjadi isu yang menarik untuk diteliti. 
Dalam beberapa tahun terakhir, penelitian mengenai akuntansi sektor publik mulai menarik perhatian banyak pihak. Hal ini terlihat dari adanya peningkatan jumlah penelitian di sektor publik pada jurnal-jurnal terakreditasi di Indonesia (Rizky dan Setiawan, 2019). Penelitian tentang penerapan SAP berbasis akrual sudah banyak dilakukan baik sebelum tahun 2015 maupun setelah adanya kewajiban untuk mengadopsi basis tersebut pada tahun 2015 (Purwanti, 2018).

Penelitian-penelitian tersebut membahas tentang kesiapan dan evaluasi penerapan SAP berbasis akrual (antara lain dapat dijumpai pada Firmansyah et al, 2020; Putra dan Sudarto, 2019; Firdaus, 2018; Safitri, 2017; Haryati, 2016; Langelo et al., 2015; Hariyanto, 2014; Yafie, 2013; Harun, Peursem, \& Eggleton, 2012; Hasiara, 2012). Hasil penelitian cukup bervariasi mulai belum siap, cukup siap dan sudah siap dengan ukuran capaian dalam persentase. Penelitian sebelumnya banyak melakukan evaluasi kesesuaian pelaksanaan SAP basis akrual dengan kebijakan akuntansi menurut Peraturan Menteri Keuangan No. 219/2013.

Meskipun akuntansi sektor publik telah menjadi area yang mulai menarik untuk diteliti, hasil riset yang secara khusus mengamati perkembangan penelitian akuntansi sektor publik di Indonesia masih sangat terbatas. Berdasarkan laman google scholar, hanya ada satu tulisan yang membahas perkembangan penelitian akuntansi sektor publik di Indonesia (Rizky dan Setiawan, 2019). Dalam studinya, mereka mengkaji dengan menggunakan hasil penelitian dari 137 artikel tentang akuntansi sektor publik pada 22 jurnal terakreditasi di Indonesia per Maret 2019. Artikel yang dipilih merupakan artikel yang terbit selama tahun 2010-2018.

Penelitian ini bermaksud mengamati hasil riset terkait akuntansi sektor publik khususnya pada instansi pemerintah pusat dan daerah pada periode sesudah penerapan basis akrual (2015-2019) yang terdiri dari 144 artikel. Pemilihan periode ini dirasa tepat karena masa tersebut adalah euphoria penerapan basis akrual. Hal ini berbeda dengan periode pengamatan Rizky dan Setiawan (2019) yang meliputi masa sebelum dan sesudah penerapan basis akrual. Disamping itu, periode tersebut merupakan masa pemerintahan baru yang mempunyai sejumlah agenda kebijakan besar dan tentu saja berimplikasi pada pengelolaan keuangan negara. Selanjutnya, Rizky dan Setiawan (2019) menggunakan 137 artikel dari 22 jurnal nasional terakreditasi. Di sisi lain, studi ini secara khusus ingin mengamati perkembangan hasil riset akutansi pemerintah pada dua jurnal terakreditasi di bawah kementerian/lembaga, yaitu ITREV (Kemenkeu) dan JTAKEN (BPK). Kedua jurnal ini 
dipilih karena memiliki beberapa persamaan dan keunikan. Pertama, ITREV dan JTAKEN sama-sama terakreditasi SINTA 2. Hal ini antara lain menunjukkan bahwa kedua jurnal tersebut menerapkan sistem seleksi yang sangat ketat terhadap artikel yang masuk. Kedua, baik ITREV dan JTAKEN sama-sama memiliki fokus area riset di bidang keuangan negara. Ketiga, mayoritas kontributor hasil riset berasal dari praktisi di instansi pemerintahan yang mengelola keuangan negara. Tulisan ini diharapkan dapat memberikan tambahan insight mengenai perkembangan hasil riset di bidang akuntansi pemerintahan dari sudut pandang para praktisi di bidang keuangan negara.

Keuangan Negara menurut Undang-Undang No. 17 Tahun 2003 tentang Keuangan Negara merupakan semua hak dan kewajiban negara yang dapat dinilai dengan uang, serta segala sesuatu, baik berupa uang atau barang, yang dapat dijadikan milik negara berhubungan dengan pelaksanaan hak dan kewajiban tersebut. Menurut Musgrave (1959), keuangan negara tidak hanya sekedar mengenai penerimaan dan belanja negara saja, tetapi juga mengenai fungsi alokasi sumber - sumber ekonomi, fungsi distribusi, dan fungsi stabilisasi, termasuk pertumbuhan ekonomi yang berdampak pada kegiatan ekonomi masyarakat.

Secara umum, ruang lingkup keuangan negara dalam UU Nomor 17 Tahun 2003 meliputi hak negara dalam pemungutan penerimaan negara, kewajiban negara untuk menyelenggarakan layanan dan membayar tagihan, pengeluaran negara, penerimaan dan pengeluaran daerah, kekayaan negara yang dipisahkan dan kekayaan pihak lain yang dikuasai oleh pemerintah. Mengingat cakupan keuangan negara bersentuhan dengan disiplin ilmu akuntansi, isu-isu penting yang membahas keuangan negara menjadi topik yang juga menjadi perhatian bagi peneliti di bidang akuntansi pemerintahan. Setiap kebijakan pemerintah yang berdampak terhadap postur APBN/APBD akan berdampak pula pada pelaporan keuangan pemerintah. Informasi yang disajikan dalam laporan keuangan pemerintah merupakan konsumsi bagi pengambil keputusan dalam mengevaluasi kebijakan pengelolaan keuangan negara.

Menurut Halim (2002:143), akuntansi pemerintahan adalah jasa pembuatan informasi mengenai keuangan negara dalam bentuk data-data kuantitatif yang bisa dijadikan kebijakan ekonomi negara. Adapun Hasanah dan Fauzi (2017:1) menjelaskan bahwa akuntansi pemerintahan dapat didefinisikan sebagai suatu aktivitas pemberian jasa untuk menyediakan informasi keuangan pemerintah berdasarkan proses pencatatan,pengklasifikasian, pengikhtisaran, suatu transaksi keuangan pemerintah serta 
penafsiran atas informasi keuangan. Akuntansi pemerintahan merupakan salah satu bidang dari administrasi pemerintahan yang mendapatkan perhatian penting. Hoesada (2020:1) menyatakan bahwa administrasi pemerintahan merupakan hal ihwal kepemerintahan dalam pengelolaan negara. Reformasi administrasi antara lain didorong oleh kondisi dan situasi memaksa, misalnya defisit anggaran pendapatan dan belanja negara (APBN), habisnya cadangan minyak bumi, kebutuhan pengendalian perekonomian bangsa dalam pasar bebas, dan berbagai jenis gejolak kondisi dunia yang menyebabkan rasionalisasi kabinet (Hoesada, 2020:2). Dengan demikian, perkembangan akuntansi pemerintahan sangat erat dengan dinamika pengelolaan keuangan di suatu negara.

Ruang lingkup akuntansi pemerintah tidak terlepas dari pembagian bidang studi akuntansi secara umum yang mencakup akuntansi keuangan, akuntansi manajemen, dan auditing. Akuntansi keuangan membahas aplikasi akuntansi secara keseluruhan, yaitu terkait masalah pencatatan dan pelaporan suatu unit ekonomi. Selain itu, teknik dan prinsip akuntansi yang diterapkan dalam unit ekonomi tersebut. Akuntansi manajemen membantu pekerjaan manajemen dalam operasi sehari-hari dan perencanaan operasional mendatang yang didasarkan dari data historis maupun data estimasi. Terakhir, auditing membahas tentang kegiatan pemeriksaan keuangan secara menyeluruh yang dilakukan secara independen dari laporan keuangan yang dihasilkan perusahaan atau unit ekonomi tersebut. Oleh karena itu, penelitian di bidang akuntansi pemerintah akan meliputi segala hal yang berkaitan dengan isu pengelolaan keuangan negara yang dapat ditinjau dari dimensi akuntansi keuangan, akuntansi manajemen, dan auditing.

Jurnal Tata Kelola dan Akuntabilitas Keuangan (JTAKEN) merupakan jurnal ilmiah yang diterbitkan oleh Direktorat Penelitian dan Pengembangan, Badan Pemeriksa Keuangan Republik Indonesia (BPK RI). Jurnal ini pertama kali diterbitkan pada tahun 2015. Penerbitan Jurnal Tata Kelola dan Akuntabilitas Keuangan didedikasikan untuk menerbitkan, menyebarluaskan, dan mendukung pelaksanaan mandat dan tujuan strategis BPK melalui artikel atau makalah ilmiah, menambah literatur dan referensi mengenai tata kelola dan tanggung jawab keuangan negara, dan mendorong penelitian dalam bidang tata kelola dan akuntabilitas keuangan negara. JTAKEN juga telah terakreditasi oleh Direktorat Jenderal Penguatan dan Pengembangan Riset Kementerian Riset, Teknologi, dan Pendidikan Tinggi Republik Indonesia dan mengantongi peringkat dua (SINTA 2) sejak tahun 2016 sampai dengan tahun 2020 berdasarkan SK No. 21/E/KPT/2018. 
Di sisi lain, Indonesian Treasury Review: Jurnal Perbendaharaan, Keuangan Negara Dan Kebijakan Publik (ITREV) diterbitkan oleh Direktorat Jenderal Perbendaharaan sejak tahun 2016. Jurnal ini merupakan publikasi ilmiah yang memuat hasil penelitian, pengembangan, kajian dan pemikiran di bidang Perbendaharan, Keuangan Negara, dan Kebijakan Publik. Jurnal ini bertujuan untuk meningkatkan dan memajukan bidang keilmuan dan praktik perbendaharaan yang mempublikasikan makalah teoritis/analitis, empiris, dan review. ITREV juga merupakan suatu wadah gagasan yang dapat digunakan sebagai sarana dialog, komunikasi, sosialisasi, dan edukasi dalam bentuk jurnal ilmiah dalam bidang Perbendaharan, Keuangan Negara, dan Kebijakan Publik. ITREV juga telah mendapatkan akreditasi dari Kemenristek dikti untuk level SINTA 2.

Dalam Jurnal Tata Kelola dan Akuntabilitas Keuangan Negara, terdapat 54 artikel dalam 5 volume. Hal tersebut tidak sesuai dengan ketentuan penerbitan jurnal yang terdapat dalam website resmi jurnal ini yang seharusnya berjumlah 60 artikel. Selisih tersebut disebabkan oleh penerbitan artikel yang terdapat pada tahun 2016 (volume II), 2017 (volume III), dan 2018 (volume IV) hanya berjumlah 5 buah artikel dalam tiap nomor atau 10 artikel dalam tiap volume. Pada tahun 2015 (volume I) dan 2019 (volume V) jumlah artikel pada tiap nomor sesuai yakni 6 buah artikel per nomor.

Sementara itu, dalam Jurnal Indonesian Treasury Review. Jurnal Perbendaharaan, Keuangan Negara Dan Kebijakan Publik, terdapat 90 artikel dalam 4 volume. Hal tersebut tidak sesuai dengan ketentuan penerbitan jurnal yang terdapat dalam website resmi jurnal ini yang seharusnya berjumlah 96 artikel. Selisih tersebut disebabkan oleh volume jurnal yang diterbitkan pada 2016 (volume I) hanya berjumlah 3 nomor, sehingga jumlah artikel pada ITRev yang diterbitkan pada tahun tersebut hanya berjumlah 18 buah artikel, dengan 6 artikel pada 3 nomor jurnal tahun 2016. Pada tahun 2017 hingga 2019 penerbitan jurnal dilakukan dengan jumlah artikel dan nomor yang sesuai.

\section{METODOLOGI PENELITIAN}

Penulis menggunakan metode penelitian yang dikembangkan oleh Hesford et al. (2007), yaitu "charting the field". Dalam riset ini, peneliti berupaya melakukan klasifikasi artikel yang terbit pada jurnal JTAKEN dan ITREV sesuai bidang akuntansinya. Selama periode 2015-2019 terdapat 144 artikel yang dipublikasikan pada kedua jurnal nasional terakreditasi sesuai gambar di bawah ini. 


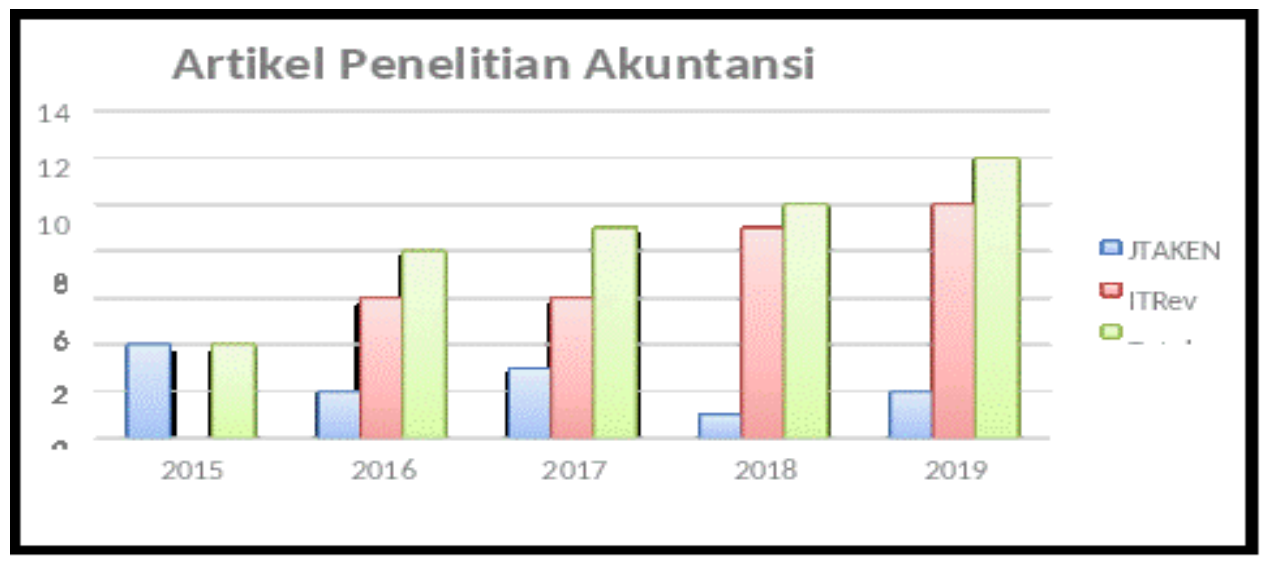

Gambar 1: Perkembangan Jumlah Penelitian Bidang Keuangan Negara

Sumber: Hasil penelitian, 2020

Pada Gambar 1 terlihat perkembangan penelitian bidang keuangan negara dalam periode lima tahun mulai dari tahun 2015 hingga 2019. Dari tahun ke tahun, jumlah penelitian keuangan negara dalam jurnal ITREV dan JTAKEN terus mengalami peningkatan. Hal ini menunjukkan bahwa minat peneliti untuk memperdalam isu-isu penting dalam pengelolaan keuangan negara semakin besar. Lebih jauh jika dikelompokkan ke dalam bidang akuntansi pemerintah, khususnya yang berkaitan dengan akuntansi keuangan, penulis mendapatkan 43 artikel yang secara khusus membahas akuntansi di instansi nonprofit tersebut. Tabel 1 berikut ini menyajikan perbandingan jumlah riset akuntansi pemerintah pada kedua jurnal terindeks SINTA tersebut. Untuk selanjutnya, yang dimaksud riset bidang akuntansi pemerintahan di paper ini adalah akuntansi pada instansi pemerintah yang fokus pada akuntansi keuangan.

Tabel 1. Perbandingan Artikel ITREV dan JTAKEN

\begin{tabular}{cccc}
\hline Jurnal & $\begin{array}{c}\text { Jumlah Nomor } \\
\text { yang Terbit }\end{array}$ & $\begin{array}{c}\text { Jumlah } \\
\text { Artikel }\end{array}$ & $\begin{array}{c}\text { Artikel Akuntansi } \\
\text { Pemerintahan }\end{array}$ \\
\hline ITREV & 15 & 90 & 31 \\
JTAKEN & 10 & 54 & 12 \\
Total & $\mathbf{2 5}$ & $\mathbf{1 4 4}$ & $\mathbf{4 3}$ \\
\hline
\end{tabular}

Sumber: Hasil penelitian, 2020

Jika dilihat dari masing-masing jurnal, perkembangan penelitian bidang akuntansi pemerintah sangatlah berbeda. ITREV yang terbit satu tahun setelah JTAKEN, justru memilik artikel akuntansi pemerintah yang lebih banyak (31 berbanding 12). Dalam empat tahun, jumlah artikel mengenai akuntansi pemerintah yang diterbitkan oleh ITREV terus mengalami 
peningkatan. Hal tersebut merupakan sesuatu yang positif dalam perkembangan keilmuan di bidang akuntansi pemerintah. Sebaliknya, JTAKEN secara keseluruhan mengalami penurunan. Artikel mengenai akuntansi pemerintah terbanyak diterbitkan pada tahun 2015 sebanyak empat artikel dan terlihat semakin menurun hingga tahun 2018 dengan satu artikel. Selanjutnya, dalam tahun 2019 artikel terkait akuntansi pemerintah yang terdapat dalam JTAKEN mulai mengalami peningkatan walaupun hanya berbeda satu artikel dari tahun sebelumnya. Dengan terlihatnya peningkatan tersebut, diharapkan agar pada tahuntahun selanjutanya penelitian dalam kedua jurnal tersebut semakin bertambah. Dalam studi ini peneliti mengkaji dengan menggunakan hasil penelitian sebanyak 43 artikel terkait akuntansi pemerintah dari 144 artikel dalam 25 nomor jurnal yang telah diterbitkan oleh dua jurnal terakreditasi SINTA 2 tersebut.

\section{HASIL PENELITIAN}

Pada penelitian ini, penulis mengelompokkan artikel-artikel penelitian dalam beberapa bidang. Tabel 2 menunjukkan tiga bidang yang banyak dibahas dalam 144 artikel tersebut. Pada urutan pertama, akuntansi pemerintah merupakan bidang yang paling mendominasi dengan persentase 30 persen. Dilanjutkan pada bidang audit sebesar 17 persen dan sistem informasi akuntansi pemerintah dengan persentase 11 persen. Apabila audit sektor publik dan sistem informasi akuntansi pemerintah dimasukkan ke dalam perspektif akuntansi pemerintah yang lebih luas, maka penelitian akuntansi yang membahas tugas dan fungsi para birokrat tersebut mencapai 84 artikel atau sebesar 58,33 persen.

Bidang yang paling mendominasi pada JTAKEN adalah bidang audit dengan persentase 41 persen (antara lain dijumpai pada Akbar dan Djazuli, 2015 dan Sangadji, 2018). Hal ini dapat dimaklumi mengingat JTAKEN diterbitkan oleh instnasi yang memiliki tugas dan fungsi di bidang pemeriksaan keuangan negara. Akuntansi pemerintahan menempati urutan kedua dengan persentase 22 persen. Ketiga, bidang sistem informasi akuntansi pemerintah dengan persentase $9 \%$ dan dilanjutkan dengan bidang-bidang yang lain. Sementara itu pada ITREV, bidang yang paling banyak dibahas hingga tahun 2019 adalah bidang akuntansi pemerintah dengan persentase 34 persen. Kondisi ini merupakan keniscayaan mengingat ITREV diterbitkan oleh instansi yang memiliki tugas dan fungsi terkait pelaporan keuangan pemerintah. Dengan persentase 12 persen sistem informasi akuntansi pemerintah menempati urutan kedua. Lalu dilanjutkan bidang ekonomi makro 
dengan persentase 10 persen. Sisa artikel tersebut terbagi dalam beberapa bidang yang dapat dilihat dalam Tabel 2 berikut ini.

Tabel 2. Klasifikasi Artikel Menurut Bidang

\begin{tabular}{|c|c|c|c|c|c|c|}
\hline \multirow[t]{2}{*}{ BIDANG } & \multicolumn{4}{|c|}{ JUMLAH ARTIKEL } & \multicolumn{2}{|c|}{ TOTAL } \\
\hline & \multicolumn{2}{|c|}{ JTAKEN } & \multicolumn{2}{|c|}{ ITREV } & & \\
\hline Akuntansi Pemerintah & 12 & $22 \%$ & 31 & $34 \%$ & 43 & $30 \%$ \\
\hline Analisis Laporan Keuangan & 0 & $0 \%$ & 3 & $3 \%$ & 3 & $2 \%$ \\
\hline Anti Korupsi & 1 & $2 \%$ & 0 & $0 \%$ & 1 & $1 \%$ \\
\hline Etika & 3 & $6 \%$ & 0 & $0 \%$ & 3 & $2 \%$ \\
\hline Audit & 22 & $41 \%$ & 3 & $3 \%$ & 25 & $17 \%$ \\
\hline Kebijakan Publik & 3 & $6 \%$ & 3 & $3 \%$ & 6 & $4 \%$ \\
\hline Perpajakan & 2 & $4 \%$ & 3 & $3 \%$ & 5 & $3 \%$ \\
\hline Sistem Informasi Akuntansi Pemerintah & 5 & $9 \%$ & 11 & $12 \%$ & 16 & $11 \%$ \\
\hline Keuangan Publik & 1 & $2 \%$ & 3 & $3 \%$ & 4 & $3 \%$ \\
\hline Sistem Informasi Akuntansi & 1 & $2 \%$ & 3 & $3 \%$ & 4 & $3 \%$ \\
\hline Manajemen Keuangan & 2 & $4 \%$ & 8 & $9 \%$ & 10 & $7 \%$ \\
\hline Pengelolaan Keuangan Negara & 1 & $2 \%$ & 8 & $9 \%$ & 9 & $6 \%$ \\
\hline Ekonomi Makro & 1 & $2 \%$ & 9 & $10 \%$ & 10 & $7 \%$ \\
\hline Hukum Keuangan Negara & 0 & $0 \%$ & 2 & $2 \%$ & 2 & $1 \%$ \\
\hline Manajemen & 0 & $0 \%$ & 3 & $3 \%$ & 3 & $2 \%$ \\
\hline Total & 54 & & 90 & & 144 & \\
\hline
\end{tabular}

Sumber: Hasil penelitian, 2020

Hesford et al. (2007) dalam penelitiannya membagi klasifikasi menjadi dua yakni berdasarkan topik penelitian dan metode penelitian yang digunakan. Penelitian ini akan membagi artikel tersebut dalam tiga klasifikasi. Klasifikasi pertama yaitu menurut topik pembahasan. Klasifikasi kedua yaitu menurut metode yang digunakan. Klasifikasi ketiga yaitu menurut tipe profesi (praktisi dan akademisi) penulis dan teori yang digunakan oleh penulis. Artikel yang diamati dalam penelitian ini berjumlah 43 artikel yang terbit dalam kurun waktu 5 tahun dari tahun 2015 hingga 2019. Klasifikasi artikel sesuai topik akuntansi pemerintah dalam jurnal JTAKEN dan ITREV ditunjukkan dalam Tabel 3 berikut ini.

Tabel 3. Artikel Penelitian Menurut Topik

\begin{tabular}{lcccc}
\hline \multicolumn{1}{c}{ Topik } & JTAKEN & ITREV & Total \\
\hline Akuntabilitas & 4 & 8 & 12 & $28 \%$ \\
Akuntansi Aset Tetap & 2 & 1 & 3 & $7 \%$ \\
Akuntansi Pendapatan & 2 & 1 & 3 & $7 \%$ \\
Akuntansi Belanja & 1 & 7 & 8 & $19 \%$ \\
Akuntansi BLU & 0 & 1 & 1 & $2 \%$ \\
Akuntansi Dana Transfer & 0 & 4 & 4 & $9 \%$ \\
Anggaran & 2 & 1 & 3 & $7 \%$ \\
Topik lainnya & 1 & 8 & 9 & $21 \%$ \\
Total & 12 & 31 & 43 & $100 \%$ \\
\hline
\end{tabular}

Sumber: Hasil penelitian, 2020 
Topik yang paling banyak dibahas dalam artikel akuntansi pemerintah adalah topik akuntabilitas laporan keuangan dengan persentase 28\% dari 43 jurnal yang diamati. Topik akuntabilitas antara lain dijumpai pada Afriyanti et al. (2015), Haryati (2016), (2018), Hadi (2017), dan Hartopo (2019). Kondisi ini antara lain menunjukkan bahwa isu terkait akuntabilitas menjadi tema yang tetap diminati oleh peneliti dalam periode setelah penerapan basis akrual. Penulis menduga hal ini sejalan dengan fenomena hasil audit atas laporan keuangan pemerintah yang menunjukkan adanya peningkatan opini yang signifikan. Sejak tahun 2016, Laporan Keuangan Pemerintah Pusat (LKPP) dan Laporan Keuangan Bendahara Umum Negara (LK BUN) memperoleh opini Wajar Tanpa Pengecualian (WTP). Disamping itu, jumlah instansi pemerintah pusat yang memperoleh opini WTP semakin banyak. Bahkan hingga akhir tahun 2019 hanya 3 Kementerian Negara/Lembaga (K/L) yang belum memperoleh opini, sisanya sebanyak $85 \mathrm{~K} / \mathrm{L}$ telah memperoleh opini terbaik dalam pelaporan keuangan. Membaiknya kualitas laporan keuangan disinyalir menjadi perhatian para peneliti untuk mengungkapkan faktor-faktor apa saja yang mempengaruhi akuntabilitas pelaporan keuangan pemerintah tersebut.

Selanjutnya terdapat topik akuntansi belanja sebanyak 8 artikel (19 persen). Riset mengenai akuntansi belanja antara lain dapat kita lihat pada Akhamdi (2017), Biswan et al (2018), Niansyah (2018), dan Prioatmaji (2019). Belanja menjadi topik yang cukup hangat dibicarakan disamping tema akuntabilitas. Penulis menduga hal ini karena para peneliti tertarik untuk mengungkapkan dampak kebijakan belanja pemerintah, khususnya terhadap pelaporan keuangan. Kebijakan belanja pada era Jokowi terlihat berbeda dari pemerintahan sebelumnya. Hal ini antara lain terlihat dari kebijakan pengeluaran infrastruktur, belanja pendidikan, dan kesehatan yang terlihat mendapatkan perhatian lebih dibandingkan sektor belanja yang lain. Belum lagi semakin maraknya penerapan kemitraan pemerintah dengan sektor swasta, menjadikan isu belanja pemerintah menjadi topik yang cukup hangat untuk didiskusikan oleh para pemerhati sektor publik.

Beberapa topik lainnya juga terlihat mewarnai hasil penelitian pada dua jurnal nasional terakreditasi tersebut (21 persen). Tema tersebut antara lain meliputi pengelolaan migas (Roziqin, 2015) procurement (Cosmas, 2017), dana desa (Ilyassa, 2016 dan Zulfian, 2017), kemandirian daerah (Haryanto, 2018), dan pembiayaan (Arham dan Firmansyah, 2019).

Di sisi lain, akuntansi Badan Layanan Umum (BLU) masih merupakan topik yang jarang dibahas. Secara prinsip, BLU merupakan sebuah entitas di bawah K/L yang memiliki 
beberapa privilege dalam pengelolaan keuangan negara. Selama kurun waktu 2015-2019, hanya satu artikel yang secara khusus menjelaskan permasalahan akuntansi BLU, yakni hasil studi Widjaja (2017) . Hal ini merupakan sinyal bahwa penelitian di bidang akuntansi BLU merupakan area yang masih cukup luas untuk dijadikan sebagai objek penelitian di masa mendatang. Masih minimnya riset mengenai akuntansi BLU pada jurnal JTAKEN dan ITREV antara lain merupakan konsekuensi dari lambannya kemunculan dan penerapan kebijakan akuntansi BLU berbasis akrual yang baru secara efektif diwajibkan di tahun 2018. Para peneliti masih memerlukan waktu untuk memahami dampak penerapan kebijakan akuntansi akrual pada entitas BLU. Topik mengenai kesadaran membayar pajak juga tidak dijumpai. Kesadaran wajib pajak dalam membayar pajak merupakan kunci penguatan penerimaan pajak dalam APBN (Aprilia dan Rani, 2020). Studi mengenai kepatuhan membayar pajak menjadi gap yang bisa diisi pada ITREV dan JTAKEN.

Metode penelitian dalam artikel ini dibagi menjadi dua kategori. Kategori pertama mencakup metode kuantitatif, kualitatif, dan campuran yang ditunjukkan dalam Tabel 4. Kategori pertama ini melihat metode penelitian dari sisi ada tidaknya pengujian hipotesis. Penelitian yang menggunakan pengujian hipotesis dikelompokkan ke dalam penelitian kuantitatif.

Tabel 4. Artikel Berdasarkan Metode Penelitian-Kategori 1

\begin{tabular}{llllllll}
\hline \multicolumn{1}{c}{$\begin{array}{c}\text { Artikel Dalam } \\
\text { Jurnal }\end{array}$} & \multicolumn{6}{c}{ Metode Penelitian } & \multirow{2}{*}{ Total } \\
\cline { 2 - 7 } & Kuantitatif & \multicolumn{2}{c}{ Kualitatif } & Campuran & \\
\hline JTAKEN & 8 & $67 \%$ & 3 & $25 \%$ & 1 & $8 \%$ & 12 \\
ITREV & 15 & $48 \%$ & 11 & $35 \%$ & 5 & $16 \%$ & 31 \\
Total & 23 & $53 \%$ & 14 & $33 \%$ & 6 & $14 \%$ & 43 \\
\hline
\end{tabular}

Sumber: Hasil penelitian, 2020

Dalam kategori kedua mencakup metode archival, deskriptif, eksploratif, eksplanatory, interpretif, naratif, studi kasus, studi pustaka, survei dan lain-lain yang ditunjukkan dalam Tabel 5. Kategori ini merupakan metode penelitian yang sifatnya lebih teknis dalam pengumpulan data. Dalam Tabel 4 memperlihatkan secara keseluruhan bahwa metode campuran yang paling sedikit digunakan dengan 14\% dibandingkan kedua metode lainnya. Adapun metode penelitian kuantitatif menjadi metode yang paling banyak digunakan dengan total 53\% dan metode penelitian kualitatif yang digunakan dalam artikel terkait akuntansi pemerintah sebesar 33\%.

Metode penelitian yang paling mendominasi dalam JTAKEN dan ITREV adalah metode penelitian kuantitas. Hal ini menunjukkan bahwa permasalahan akuntansi 
pemerintah telah dapat diidentifikasi secara data statistik melalui pengujian hipotesis. Kondisi ini juga menyiratkan bahwa data sekunder terkait dengan informasi akuntansi pemerintahan telah dapat diakses oleh beragam peneliti. Selanjutnya, metode kualitatif menempati urutan kedua dan terakhir adalah metode campuran. Metode yang mendominasi pada kedua jurnal tersebut sesuai dengan persentase secara keseluruhan.

Penggunaan metode campuran (mixed method) yang relatif minim mengindikasikan bahwa metode ini masih perlu dikembangkan untuk riset akuntansi pemerintah di masa mendatang. Hasil pengujian statistik tidak selamanya cukup memuaskan untuk menjawab pertanyaan penelitian. Diperlukan data tambahan dari teknik pengumpulan data primer seperti wawancara, observasi maupun focused group discussion (FGD). Terlebih fenomena akuntansi pada sektor publik ini tidak selalu dapat dianalogikan dengan potret pada sektor privat. Terdapat karakteristik yang sangat unik yang tidak ada pada organisasi yang mengejar laba, antara lain adanya penerapan akuntansi anggaran. Penerapan mixed method seyogianya akan menjadi langkah yang ideal untuk mengungkapkan kasus-kasus dalam pengelolaan keuangan negara di masa mendatang.

Tabel 5 memperlihatkan artikel dalam jurnal JTAKEN di dominasi oleh metode studi pustaka dengan jumlah 7 artikel atau sebesar $58 \%$ dan diikuti dengan metode deskriptif dengan jumlah 4 artikel atau sebesar 33\%. Di sisi lain, dalam jurnal ITREV, metode yang paling mendominasi adalah metode penelitian deskriptif dan studi pustaka dengan jumlah masing-masing 8 artikel atau sebesar 26\% yang diikuti dengan metode survei sejumlah 6 artikel atau sebesar 19\%.

Tabel 5. Artikel Berdasarkan Metode Penelitian-Kategori 2

\begin{tabular}{lcccccc}
\hline \multirow{2}{*}{ Metode Penelitian } & \multicolumn{3}{c}{ Artikel Dalam Jurnal } & \multicolumn{3}{c}{ Total } \\
\cline { 2 - 7 } & \multicolumn{3}{c}{ JTAKEN } & \multicolumn{3}{c}{ ITRev } \\
\hline Archival & 0 & $0 \%$ & 2 & $6 \%$ & 2 & $5 \%$ \\
Deskriptif & 4 & $33 \%$ & 8 & $26 \%$ & 12 & $28 \%$ \\
Eksploratif & 0 & $0 \%$ & 2 & $6 \%$ & 2 & $5 \%$ \\
Eksplanatori & 0 & $0 \%$ & 1 & $3 \%$ & 1 & $2 \%$ \\
Interpretif & 1 & $8 \%$ & 0 & $0 \%$ & 1 & $2 \%$ \\
Naratif & 0 & $0 \%$ & 1 & $3 \%$ & 1 & $2 \%$ \\
Studi Kasus & 0 & $0 \%$ & 1 & $3 \%$ & 1 & $2 \%$ \\
Studi Pustaka & 7 & $58 \%$ & 8 & $26 \%$ & 15 & $35 \%$ \\
Survei & 0 & $0 \%$ & 6 & $19 \%$ & 6 & $14 \%$ \\
Lain-Lain & 0 & $0 \%$ & 2 & $6 \%$ & 2 & $5 \%$ \\
Total & 12 & & 31 & & 43 & \\
\hline Sumyyyyyyyyy
\end{tabular}

Sumber: Hasil penelitian, 2020 
Secara keseluruhan, metode yang paling banyak digunakan adalah metode studi pustaka sejumlah 15 artikel atau sebesar 35\%. Metode deskriptif merupakan metode yang paling banyak kedua setelah metode studi pustaka dengan persentase $28 \%$ atau sejumlah 12 artikel. Sedangkan artikel-artikel lainnya menggunakan metode survei, archival, eksploratif, eksplanatori, interpretif, naratif, studi kasus dan metode lain-lain.

Masifnya penggunaan studi kepustakaan bisa jadi disebabkan adanya keterbatasan informasi pada pemerintahan untuk isu-isu tertentu. Terdapat beberapa informasi yang memang tidak bisa dibuka secara publik. Meskipun informasi terkait laporan keuangan merupakan informasi yang bersifat free access, terdapat hal-hal yang sulit diungkapkan seperti keputusan anggaran. Terdapat nuansa politik dalam keputusan anggaran karena melibatkan peran anggota DPR/DPRD. Adanya kesulitan untuk memperoleh informasi yang bersifat classified tersebut diduga mendorong penggunaan metode studi pustaka yang cukup banyak pada kedua jurnal nasional terakreditasi tersebut.

Klasifikasi yang terakhir merupakan klasifikasi menurut tipe pekerjaan penulis, apakah praktisi atau akademisi, dan teori yang digunakan oleh penulis. Data terkait pekerjaan penulis artikel dicantumkan dalam Tabel 6.

Tabel 6. Tabulasi Tipe Pekerjaan Penulis Artikel

\begin{tabular}{lcrrrrr}
\hline \multirow{2}{*}{ Jurnal } & \multicolumn{7}{c}{ Tipe Profesi } \\
\cline { 2 - 7 } & \multicolumn{2}{c}{ Praktisi } & \multicolumn{2}{c}{ Akademisi } & \multicolumn{2}{c}{ Total } \\
\hline JTAKEN & 13 & $68 \%$ & 6 & $32 \%$ & 19 & $100 \%$ \\
ITRev & 24 & $60 \%$ & 16 & $40 \%$ & 40 & $100 \%$ \\
Total & 37 & $63 \%$ & 22 & $37 \%$ & 59 & $100 \%$ \\
\hline
\end{tabular}

Sumber: Hasil penelitian, 2020

Total penulis artikel sebanyak 59 orang, 19 orang berasal dari JTAKEN dan 40 orang berasal dari ITREV. Dari seluruh penulis artikel terkait akuntansi pemerintah dalam JTAKEN, $68 \%$ penulisnya memiliki tipe profesi praktisi dan tipe profesi akademisi sebesar $32 \%$. Dalam ITREV, penulis dengan tipe profesi praktisi juga lebih mendominasi daripada tipe profesi akademisi dengan persentase 60\%. Dari kedua hal tersebut kita ketahui bahwa penulis dengan tipe praktisi lebih mendominasi ketimbang penulis dengan tipe profesi akademisi. Sebelumnya, kita ketahui bahwa JTAKEN dan ITREV merupakan jurnal terakreditasi yang diterbitkan oleh dua lembaga, yaitu BPK dan DJPB. Otomatis pegawai-pegawai yang memiliki sebuah artikel penelitan lebih memilih untuk menyampaikan artikelnya kepada lembaga mereka masing-masing. Sedangkan bagi penulis dengan tipe profesi akademisi 
atau bukan pegawai dalam lembaga tersebut memiliki banyak sekali pilihan untuk menerbitkan artikelnya sehingga tersebar di berbagai jurnal.

Ditinjau dari sisi penggunaan teori, diketahui bahwa teori yang paling sering digunakan oleh penulis untuk mengembangkan artikelnya yaitu teori kebijakan publik, akuntabilitas, teori keagenan, dan negara kesejahteraan. Lalu, terdapat artikel-artikel yang menggunakan teori desentralisasi dan teori institusional. Teori yang digunakan lebih banyak berkaitan dengan kebijakan ekonomi makro. Hal ini dapat dimaklumi mengingat sebagian besar kontributor artikel merupakan praktisi yang bersentuhan dengan kebijakan publik khususnya keuangan negara. Sementara itu, teori keagenan cukup relevan digunakan dalam riset akuntansi sektor pemerintahan karena berkaitan dengan upaya monitoring dari rakyat selaku principal kepada para birokrat selaku agent. Fungsi monitoring tersebut merupakan wujud dari implementasi good governance (Raksono dan Wirjawan, 2019).

Secara khusus, peneliti menemukan beberapa artikel menarik yang membahas dampak penerapan basis akrual. Terdapat empat artikel yang membahas secara khusus mengenai akuntansi berbasis akrual, yaitu : "Analisis Atas Pengakuan Pendapatan Pajak dan Migas saat Permulaan Implementasi Basis Akrual pada Akuntansi Pemerintah Pusat", "Perjalanan Akuntansi Aset Tetap pada Pemerintah Daerah di Indonesia dan Capital Charging sebagai Wacana Pengembangannya", "Analisis Kualitas Implementasi Akuntansi Berbasis Akrual" dan "Dampak Penerapan Basis Akrual terhadap Kualitas Transparansi Fiskal Pemerintah". Keempat artikel tersebut menyajikan policy implication maupun future research yang layak untuk ditindaklanjuti. Sebagai contoh policy implication dari Yuwana, et al., (2016) dalam artikelnya "Analisis Atas Pengakuan Pendapatan Pajak dan Migas saat Permulaan Implementasi Basis Akrual pada Akuntansi Pemerintah Pusat" antara lain menjelaskan perlunya pengungkapan pendapatan PNBP Migas dengan menggunakan asas bruto. Hal ini dimaksudkan agar dapat mengevaluasi kinerja pengelolaan PNBP migas berdasarkan informasi akuntansi.

Hammam (2017) menginformasikan potensi riset di masa mendatang dalam artikel "Perjalanan Akuntansi Aset Tetap pada Pemerintah Daerah di Indonesia dan Capital Charging sebagai Wacana Pengembangannya". Topik berkaitan dengan akuntansi asset tetap khususnya berkaitan dengan capital charging memerlukan kajian lebih lanjut agar lebih mangkus dan sangkil.

Selanjutnya, Wahyudi (2019) dalam artikelnya "Analisis Kualitas Implementasi Akuntansi Berbasis Akrual" memberikan beberapa rekomendasi untuk mengatasi 
permasalahan penerapan akuntansi keuangan di instansi pemerintah. Rekomendasi tersebut antara lain perlunya pedoman akuntansi basis akrual yang lebih memudahkan, pengembangan sistem aplikasi dan peningkatan kualitas SDM.

Terakhir, Putra dan Sudarto (2019) dalam "Dampak Penerapan Basis Akrual terhadap Kualitas Transparansi Fiskal Pemerintah" menyampaikan beberapa harapannya terhadap hasil penelitian yang telah dilakukan. Beberapa saran yang diajukan antara lain membuat kebijakan akuntansi dalam bentuk panduan teknis sebagai pedoman akuntansi akrual untuk masing-masing $\mathrm{K} / \mathrm{L}$, mengoptimalkan fungsi auditor internal dan penerapan manajemen risiko fiskal. Adapun future research bagi penelitian berikutnya antara lain dengan memperluas survei lintas negara menggunakan model dan metode yang sama dengan penelitian sebelumnya dan menyesuaikan keberagaman kebudayaan, politik, sosial, dan struktur ekonomi.

\section{SIMPULAN}

Studi ini bertujuan untuk melakukan reviu perkembangan penelitian akuntansi pemerintahan sejak tahun 2015 pada dua jurnal nasional terakreditasi. Perkembangan hasil riset di bidang akuntansi pemerintahan khususnya untuk area akuntansi keuangan menunjukkan kecenderungan meningkat dalam lima tahun terakhir. Hal ini mengindikasikan bahwa topik akuntansi keuangan pada instansi pemerintahan semakin diminati oleh para peneliti sejak penerapan basis akrual di tahun 2015. Secara keseluruhan, dari 43 artikel topik yang paling sering dibahas pada penelitian akuntansi pemerintah yaitu akuntabilitas laporan keuangan. Sementara itu beberapa area yang masih terbatas pembahasannya adalah akuntansi Badan Layanan Umum (BLU). Topik BLU diharapkan dapat dikembangkan pada riset mendatang seiring dengan penerapan kebijakan akuntansi akrual di BLU yang efektif sejak tahun 2018. Topik kesadaran membayar pajak juga menjadi peluang pada jurnal nasional terakreditasi tersebut.

Penelitian di bidang akuntansi pemerintah memberikan beragam implikasi kebijakan bagi perbaikan kualitas pengelolaan keuangan negara. Oleh karena itu penelitian ini menjadi sangat penting untuk memberikan sumbangsih pemikiran bagi pemerintah dalam mengoptimalkan APBN dan APBD di masa mendatang. Dengan melihat hasil dari penelitian ini, masih banyak topik-topik yang masih sedikit atau belum pernah dibahas mengenai akuntansi pemerintah. Metode penelitian yang dilakukan sangat beragam namun baru metode studi pustaka dan analisis deskriptif yang paling banyak digunakan. Oleh karena itu, 
penulis ingin mencoba memberikan beberapa saran demi meningkatkan perkembangan akuntansi pemerintah dalam bidang keilmuan, terutama penelitian dalam jurnal terakreditasi di Indonesia.

Saran untuk penelitian mendatang dapat penulis sampaikan berikut ini. Pertama, perlunya untuk mengembangkan penelitian yang masih hangat seperti akuntabilitas pelaporan keuangan dengan mengembangkan penggunaan variabel moderasi dan mediasi. Penggunaan data primer juga diharapkan dapat mengungkapkan hal-hal yang sulit diukur seperti faktor kepemimipinan, komitmen pegawai, dan etika. Kedua, studi selanjutnya perlu mendalami topik yang masih jarang dibahas pada penelitian- penelitian sebelumnya seperti akuntansi BLU dan PNBP. Ketiga, riset selanjutnya dapat mengembangkan mixed method untuk memperkaya perspektif dalam riset akuntansi pemerintah.

\section{DAFTAR PUSTAKA}

Adi, Cosmas S.W. (2017). Analisis Penerapan E-Procurement Menggunakan Sistem Pengadaan Secara Elektronik: Studi Kasus pada Layanan Pengadaan Secara Elektronik (LPSE) Kementerian Keuangan Papua Barat. Indonesian Treasury Review: Jurnal Perbendaharaan, Keuangan Negara dan Kebijakan Publik, Vol.2, No.2, 2017, Hal.1-16

Afriyanti, D., Harpanto G.S., dan Fahrizal Noor. (2015). Penilaian Indeks Akuntabilitas Instansi Pemerintah. Jurnal Tata Kelola \& Akuntabilitas Keuangan Negara, 1(1), 21- 42

Akbar, Bahrullah dan Achmad Djazuli. (2015). Audit Keuangan dan Kesejahteraan Rakyat Studi pada Kabupaten Badung, Tabanan dan Kota Denpasar Tahun 2013. Jurnal Tata Kelola \& Akuntabilitas Keuangan Negara, 1(1), 1- 19

Akhmadi, Muhammad Heru. (2017). Tinjauan Pelaksanaan Pembayaran Non Tunai Pada Belanja Bantuan Sosial: Studi Kasus Program Keluarga Harapan. Indonesian Treasury Review: Jurnal Perbendaharaan, Keuangan Negara dan Kebijakan Publik, Vol.2 No.1, 2017, Hal. 99-114.

Aprilia, A., \& Rani, P. (2020). Pengaruh Metode Pelatihan, Instruktur Pelatihan, Materi Pelatihan Dan Kompetensi Kerja Terhadap Prestasi Kerja Relawan Pajak (Studi Empiris pada Relawan Pajak 2019 Kantor Wilayah Direktorat Jenderal Pajak Jakarta Selatan II). Jurnal Akuntansi dan Keuangan, 9(2), 91-108.

Ardhi, Ilyassa. (2016). Keterlambatan Implementasi Penyaluran Dana Desa. Indonesian Treasury Review: Jurnal Perbendaharaan, Keuangan Negara dan Kebijakan Publik Vol.1, No.3, Hal. 35- 48.

Arham, Amardianto dan Amrie Firmansyah. (2019). Catastrophe Bond Sebagai Instrumen Pembiayaan Pemerintah dalam Penanggulangan Bencana Alam di Indonesia. Indonesian Treasury Review: Jurnal Perbendaharaan, Keuangan Negara dan Kebijakan Publik, 4(4), 339-349 
Ariansyah, Sintong. (2018). Analisis Pengaruh Pengeluaran Pemerintah terhadap Indeks Pembangunan Manusia Melalui Pendapatan Domestik Regional Bruto di Indonesia. Indonesian Treasury Review: Jurnal Perbendaharaan, Keuangan Negara dan Kebijakan Publik, 3(4), 270-283

Badan Pendidikan dan Pelatihan Keuangan Tim Pusdiklat Pengembangan Sumber Daya Manusia. (2014). Modul Pengelolaan Keuangan Negara, Jakarta

Biswan, Ali T., dan Fitri Irka Wahyu Niansyah. (2018). Analisis Varians Anggaran Belanja untuk Pengukuran Kinerja (Studi Terapan pada Kpp Badan dan Orang Asing). Indonesian Treasury Review: Jurnal Perbendaharaan, Keuangan Negara dan Kebijakan Publik, 3(4), 348-363

Blöndal, Jón R. (2003). Accrual Accounting and Budgeting. Key Issues and Recent Developments Journal. Vol. 3 No. 1. OECD.

BPKP. (2002). Modul Pelatihan Dasar-Dasar Akuntansi 1. Jakarta : Badan Pengawasan Keuangan dan Pembangunan. Dalam Pelaksanaan Otonomi Daerah". Jurnal Bisnis dan Akuntansi. Vol 3, No.2:441- 456

Djamhuri, A., Wirawan P.Y., dan Wuryan A. (2016). Analisis Atas Pengakuan Pendapatan Pajak dan Migas saat Permulaan Implementasi Basis Akrual pada Akuntansi Pemerintah Pusat. Jurnal Tata Kelola \& Akuntabilitas Keuangan Negara, 2(1), 71 - 88

Firdaus, M.I. (2018). Pengaruh Pemanfaatan Teknologi Informasi, Kepatuhan atas Peraturan, dan Kompetensi SDM terhadap Kualitas Laporan Keuangan Kementerian/Lembaga(LKKL). Indonesian Treasury Review: Jurnal Perbendaharaan, Keuangan Negara dan Kebijakan Publik, 3(2), 129-142.

Firmansyah, Amrie, Wibowo, Puji, dan Puspitarini, Intan. (2020). Implementation of Accrual Based Accounting on Regional Property in Indonesia: Competence Employees and Organizational Commitments Perspective. International Journal of Psychosocial Rehabilitation, 24(7): 9502-9512.

Haryanto, Joko T. (2018). Kemandirian Daerah dan Prospek Ekonomi Wilayah Kalimantan. Indonesian Treasury Review: Jurnal Perbendaharaan, Keuangan Negara dan Kebijakan Publik, 3(4), 312- 328.

Hadi, Waskito. (2017). Pengaruh Earning Performance dan Proporsi PAD LKPD 2015 terhadap Kemandirian Daerah di Jawa Tengah. Jurnal Tata Kelola \& Akuntabilitas Keuangan Negara, 3 (1), 1-19

Hammam, Muhammad. (2017). Perjalanan Akuntansi Aset Tetap pada Pemerintah Daerah di Indonesia dan Capital Charging sebagai Wacana Pengembangannya. Jurnal Tata Kelola \& Akuntabilitas Keuangan Negara, 3(1), 21 - 31

Hartopo, Wing. (2019). Evaluasi dan Perumusan Saran Tindak atas Problematika Pelaporan Keuangan Direktorat Jenderal Bea dan Cukai dengan Pendekatan Soft Systems Methodology (SSM). Indonesian Treasury Review: Jurnal Perbendaharaan, Keuangan Negara dan Kebijakan Publik, 3(3), 26-268.

Harun, Peursem, K. V., \& Eggleton, I. (2012). Institutionalization of Accrual Accounting in the Indonesian Public Sector. Journal of Accounting \& Organizational Change, 8(3), 257-285. 
Haryanto, Agus. (2014). Penggunaan Basis Akrual Dalam Akuntansi Pemerintahan Di Indonesia. Dharma Ekonomi, 36(XIX):1-11.

Haryanto, Joko T. (2018). Kemandirian Daerah dan Prospek Ekonomi Wilayah Kalimantan. Indonesian Treasury Review: Jurnal Perbendaharaan, Keuangan Negara dan Kebijakan Publik, 3(4), 312-328

Haryati, Tri. (2016). Anteseden Kualitas Laporan Keuangan Pemerintah Daerah. Indonesian Treasury Review: Jurnal Perbendaharaan, Keuangan Negara dan Kebijakan Publik Vol. 1 No.3, 2016, Hal.1-18.

Hasanah, Nurmalia dan Fauzi, Achmad. (2017). Akuntansi Pemerintahan. Bogor: In-Media.

Hasiara, L. (2012). Sikap dan Perilaku Pejabat, Unit SKPD dalam Pengelolaan APBD dan Aset Daerah. Jurnal Akuntansi Multiparadigma, 3(1), 101-110.

Herianti, Eva. 2019. Budget Turbulence And Budget Deviation: Do Local Government Have The Ability To Reduce Them?. Jurnal Tata Kelola \& Akuntabilitas Keuangan Negara, 5(1), 1-20.

Hoesada, Jan. (2020). Bunga Rampai Akuntansi Pemerintahan, Buku Dua. Jakarta: Salemba Empat.

Istiqomah, N. Analisis Implementasi Government Finance Statistics di Indonesia: Pendekatan Teori Institusional. Indonesian Treasury Review: Jurnal Perbendaharaan, Keuangan Negara dan Kebijakan Publik, Vol.3, No.2, Hal.69-90

Jensen, M and Mecking, W. (1976). Theory of The Firm: Managerial Behaviour, Agency Costs and Ownership Structure. Journal of financial Economics 3 (4):305-360

Lambert, R.A. (2001). Contracting Theory and Accounting." Journal of Accounting \& Economics, (32): 3 - 87.

Langelo, Friska, Saerang, David Paul Elia, dan Alexander, Stanly Winylson. (2015). Analisis Penerapan Standar Akuntansi Pemerintahan Berbasis Akrual Dalam Penyajian Laporan Keuangan Pada Pemerintah Kota Bitung. Jurnal EMBA, 3(1): 1-8.

Mangkunegara, I. (2015). Pengaruh Karakteristik Keuangan Dan Hasil Pemeriksaan Pada Kesejahteraan Masyarakat Di Provinsi Sumatera Utara. Jurnal Tata Kelola \& Akuntabilitas Keuangan Negara, 1(2), 141 - 155

Mongan, Jehuda J.S. (2019). Pengaruh Pengeluaran Pemerintah Bidang Pendidikan Dan Kesehatan terhadap Indeks Pembangunan Manusia di Indonesia. Indonesian Treasury Review: Jurnal Perbendaharaan, Keuangan Negara dan Kebijakan Publik, 163-176

Mulya, I Made Oka., I Wayan Yeremia Natawibawa, and Wahyu Hendarto Yoh. (2019). Transparency And Accountability As Determinants In The Financial Management Of Universities: A Study On State Universities In Malang City. Jurnal Tata Kelola \& Akuntabilitas Keuangan Negara, 5( 1), 57-72

Musgrave, Richard A. (1959). Theory of public finance, New York: McGraw-Hill.

Musgrave, Richard A. and Musgrave, Peggy B. (1983). Public Finance In Theory and Practice, McGraw Hill International Book, Third Edition. Asian Student Edition, Singapore National Printers (Pte) Ltd. First Impression. 
Pamugar, Haris. (2017). Pemeriksaan Subsidi Bahan Bakar Minyak (Bbm) untuk Kesejahteraan Rakyat. Jurnal Tata Kelola \& Akuntabilitas Keuangan Negara, 3(1), 49 67

Prioatmaji, Dwi. (2019). Peningkatan Efisiensi Belanja Perjalanan Dinas pada Kementerian/Lembaga dengan Model Shared Service. Indonesian Treasury Review: Jurnal Perbendaharaan, Keuangan Negara dan Kebijakan Publik, 4(1), 71-86.

Purwanti, Lilik. (2018). Apakah Standar Akuntans Berbasis Akrual Membawa Berkah? Jurnal Akuntansi Multiparadigma, Vol 9 (1): 173-191.

Putra, Donny Maha dan Sudarto. (2019). Dampak Penerapan Basis Akrual terhadap Kualitas Transparansi Fiskal Pemerintah. Indonesian Treasury Review: Jurnal Perbendaharaan, Keuangan Negara dan Kebijakan Publik, 4(3), 231

Rajan, M.V. and R.E. Saouma. (2006). Optimal Information Asymmetry. The Accounting Review, Vol. 81, No. 3, 677-712.

Raksono, S., \& Wirjawan, R. S. (2019). Pengaruh Good Corporate Governance, Ukuran Perusahaan, Dan Kinerja Keuangan Terhadap Nilai Perusahaan. Jurnal Akuntansi dan Keuangan, 8(2), 189-202.

Ramdhani, A., Amin, A.S. \& Ramdhani, M.A. (2014). Writing a Literature Review Research Paper: A Step-by-step Approach

Rasul, Syahrudin. (2003). Pengintegrasian Sistem Akuntabilitas Kinerja dan Anggaran dalam Perspektif UU NO. 17/2003 Tentang Keuangan Negara, Jakarta: PNRI

Roziqin. (2015). Pengelolaan Sektor Minyak Bumi di Indonesia Pasca Reformasi: Analisis Konsep Negara Kesejahteraan. Jurnal Tata Kelola \& Akuntabilitas Keuangan Negara, $1(2), 191-205$

Safitri, Devi. (2017). Faktor Faktor Yang Mempengaruhi Penerapan Standar Akuntansi Pemerintahan Berbasis Akrual (Studi Pada SKPD Pemerintah Kabupaten Bengkalis). Jurnal Akuntansi, 5(2):174-189.

Sangadji, Sut Mutiah. (2018). Pengaruh Inventarisasi Aset Terhadap Legal Audit dan Penilaian Aset (Studi Kasus pada Pemerintah Kota Bandung). Jurnal Tata Kelola \& Akuntabilitas Keuangan Negara, 4(1), 41 - 62

Saputra, R.O. Analisis Implementasi Government Finance Statistics di Indonesia: Pendekatan Teori Institusional. Indonesian Treasury Review: Jurnal Perbendaharaan, Keuangan Negara dan Kebijakan Publik, Vol.3, No.1, 35-42

Setyawan, Budhi. (2018). Kajian Pengenaan Cukai terhadap Gula. Indonesian Treasury Review: Jurnal Perbendaharaan, Keuangan Negara dan Kebijakan Publik, 3(4), 284-295

Setiawan, Doddy dan Luthfia Maha Reni. (2019). Pengaruh Variabel Kebutuhan Fiskal terhadap Alokasi DAU Pada Daerah Bercirikan Kepulauan. Indonesian Treasury Review: Jurnal Perbendaharaan, Keuangan Negara dan Kebijakan Publik, 4(3), 28-50

Shauki, Elvia R., dan Joko Kisworo. (2019). Teori Institusional dalam Penyusunan dan Publikasi Laporan Tahunan Sektor Publik (Studi Kasus pada Kementerian dan Lembaga Negara di Indonesia). Indonesian Treasury Review: Jurnal Perbendaharaan, Keuangan Negara dan Kebijakan Publik, 4(4), 305-321. 
Sigit, Tri A. (2019). Faktor-faktor yang Memengaruhi Tingkat Akurasi Rencana Penarikan Dana (RPD) Harian Satuan Kerja Kementerian/Lembaga. Indonesian Treasury Review: Jurnal Perbendaharaan, Keuangan Negara dan Kebijakan Publik, 4(2), 14-161

Sukarno. (2018). Penerapan Perampasan Aset di Indonesia sebagai Upaya Pemulihan Kerugian Negara dalam Perspektif Keuangan Negara. Indonesian Treasury Review: Jurnal Perbendaharaan, Keuangan Negara dan Kebijakan Publik, 3(4), 296311

Surya, Bramiana Cahya. (2016). Pengaruh Kapasitas Fiskal dan Restrukturisasi Pinjaman Terhadap Kinerja Pembayaran Pinjaman Pemerintah Daerah. Indonesian Treasury Review: Jurnal Perbendaharaan, Keuangan Negara dan Kebijakan Publik Vol.1 No.3, 2016, Hal.69-83

Ujianto, D. A., dan Fitri Isharyanto. (2016). Pengelolaan Museum Pemerintah dengan Model Badan Layanan Umum (Suatu Tinjauan). Jurnal Tata Kelola \& Akuntabilitas Keuangan Negara, 2(1), 89 - 109.

Wahyudi, Indra. (2019). Analisis Kualitas Implementasi Akuntansi Berbasis Akrual. Indonesian Treasury Review: Jurnal Perbendaharaan, Keuangan Negara dan Kebijakan Publik, 4(1), 12-22

Waryanto, Puput. (2017). Pengaruh Belanja Modal Terhadap Pertumbuhan Ekonomi di Indonesia. Indonesian Treasury Review: Jurnal Perbendaharaan, Keuangan Negara dan Kebijakan Publik Vol.2 No.1, Hal. 35-55

Wulansari, Dyah, Muliati dan Rossanto Dwi H. (2019). Alokasi Anggaran Publik dan Pengentasan Kemiskinan di Pulau Kalimantan. Indonesian Treasury Review: Jurnal Perbendaharaan, Keuangan Negara dan Kebijakan Publik, 4(4), 371-384

Yafie, M. Dhairolly. (2013). Penerapan Basis Akrual Pada Standar Akuntansi Pemerintahan Indonesia. Jurnal Akuntansi Unesa, 2(1):1-24.

Zaenudinsyah, Fandi. (2016). Analisis Faktor Penyebab Penumpukan Pencairan Dana APBN pada Akhir Tahun Anggaran. Indonesian Treasury Review: Jurnal Perbendaharaan, Keuangan Negara dan Kebijakan Publik 1(1), 67-83

Zulfian, Rusli. (2017). Analisis Implementasi Dana Desa di Wilayah Maluku Utara. Indonesian Treasury Review: Jurnal Perbendaharaan, Keuangan Negara dan Kebijakan Publik, Vol.2, No.3, 2017, Hal.55-80

Zulkifli. (2017). Analisis Portofolio Optimal Dana Pengembangan Pendidikan Nasional pada Lembaga Pengelola Dana Pendidikan. Indonesian Treasury Review: Jurnal Perbendaharaan, Keuangan Negara dan Kebijakan Publik, Vol.2, No.4, 2017, Hal.65-72

Widjaja, Muliadi dan Syahri Azda P. dan. (2017). Analisis Kerentanan Keuangan Badan Layanan Umum Tahun 2012 - 2014. Indonesian Treasury Review: Jurnal Perbendaharaan, Keuangan Negara dan Kebijakan Publik, Vol.2 No.1, 2017, Hal. 1-15 